\title{
HENK MAIER
}

\section{Explosions in Semarang Reading Malay tales in 1895}

\author{
Riding trains, reading tales
}

On the morning of 12 December 1895, a well-dressed young man enters the railway station in the city of Semarang. He purchases a ticket, walks around on the platform, and then gets on the train to Solo, ready for departure. Once the machine starts moving, the man looks out of the window, visibly confused. He turns to his fellow passengers, many of them unknown to him. In Malay, the language of travellers, he exchanges information, tells and hears stories, discusses issues of daily life, of himself, of the people who, out in the rice fields, on the roads, in the plantations, are staring at the roaring machine passing by. Now and then the man looks into his own heart again, losing himself in empty thoughts. And with every tick of his watch the landscape out there changes its appearance. And farmers and labourers stop their work, distracted by the awesome noise of the iron monster. ${ }^{1}$

These could be the knots in a Malay tale written in the final decade of the nineteenth century, about a young man in the city of Semarang travelling back home by train, only to find his relatives gone. Writing about travelling by train in the 1890s could have opened up to novel ways of talking about the world. Travelling by train exposed passengers, spectators, and readers to new ideas about life, time, and place. Tales about trains would have evoked the new structure of feeling and the novel forms of language that were slowly but steadily spreading over Java and beyond, examining modern notions of literature, progress, boredom, anxiety, and nationalism in the process.

1 Another version of this essay was presented at Seminar Sastera Cetak Abad ke-19, organized by Dewan Bahasa dan Pustaka, Kuala Lumpur, 14-15 December 2004. It is dedicated to Hashim Awang, opener of gaps, and Fatimah Busu, teller of tales.

H.M.J. Maier is Luce Professor Southeast Asian Studies at the University of California, Riverside and obtained his PhD from Leiden University. Specializing in comparative literature and Indonesian languages and literatures he is the author of, most recently, 'Escape from the green and gloss of Java; Hella S. Haasse and Indies literature', Indonesia 77, 2004, pp. 79-107 and We are playing relatives; A survey of Malay writing, Leiden: KITLV Press, 2004. Professor Maier may be contacted at hendrik.maier@ucr.edu. 
However, neither trains nor train rides play a prominent role in the printed storybooks that appeared in the Malay lands ${ }^{2}$ after 1875, no matter how effectively they might have figured in evocations of the experiences of becoming modern. Neither do other objects and acts that could have been foregrounded in vignettes of acting and speaking modern. Postal stamps, streetlights, and catalogues, for instance, and using the telegraph, collecting dictionaries, and taking a shower. Instead, early printed Malay tales are situated in the past, an isolated site, separated from the present which, by definition, will never reach closure. It seems as if Malay writers did not know what conclusions they could draw from contemporaneity, what to make of the obtrusive present before their eyes and ears; they preferred to turn their words to the past as the site where conversations and thoughts about events and relationships could be presented in conclusive and comprehensive forms.

Closure and presence are the temporal features with which science-fiction tales, exploring modernity and its dynamics beyond the borders of this world, would be struggling; performing like convex mirrors of historical tales, they would end at a time that is ahead of the present. Foregrounding machines that have not yet materialized in real life, they would offer their readers open endings about a site and a time that lie ahead of us. ${ }^{3}$

Of course, this short summary of conflicting and possible movements of late nineteenth-century Malay narratives should remind us of tales from days of old, and it is tempting to make yet another generalization: Malay tales that were penned before 1875 (manuscripts are still being read until the present day, alongside books and newspapers) tended to be outside of time. Or, more precisely, their words were striving to present their audience with a timeless and infinite world. Manuscripts pointed to Never-Never Land, so strongly so that they could refer to past, present, and future at once. Now called romances, myths, histories, and epics, they took place in regions around Negeri Anta-Beranta, yet they were pervaded with casual information about the Malay lands, saturated with fragments of tales that referred to real life, strong enough to reflect as well as model the daily life of their audience within the framework of cosmic contemporaneity. In the Malay lands, these manuscripts were complemented by orally presented tales, poems, sketches, gossip, and rumours that did not reach beyond the particular and, hence, continuously defied the authority of manuscript recitals. And in the second

2 The term 'Malay lands' refers to the coastal areas around the Strait of Malacca, the Java Sea, and the South China Sea.

3 Science fiction can be defined as a form of writing 'that explores the marvels of discovery and achievement that may result from future developments in science and technology' (Abrams 1988:195). 
half of the nineteenth century, other complements emerged, embedded in the machinery of railroads, newspapers, and postal services: an ever expanding series of printed books that questioned the authority of manuscripts and their recitals in more radical ways than even their contemporary competitors - newspapers and oral tales - could ever have done.

In the volatile book market that these printed materials created in the Malay lands towards the end of the nineteenth century, nearly all tales offered a sense of closure as sketched above. Only a few tales did not comply with the conclusive sense of closure. Tan Teng Kie (1891), Sja'ir djalanan kreta api, for instance, and W.N.J.G. Claasz (1895), Romah asêp (Stoomhuis): these tales offered readers inconclusive pictures of their contemporary world. Not only did they deal with a novel object, trains; they also had endings that opened up to the future and to the anxiety and boredom that come with it. They were different. They were counterpoints in the ever expanding and contracting configuration of Malay writing. Tan's poem explores the significance of this mechanical novelty, the train, and shows ambivalence as to its effects: a railroad brings excitement and profit, but also misery and fear. Claasz's prose explores the contemporary world by way of a futuristic train which eventually explodes with a big bang, a disruptive event that tries to stop the colonial masters from continuing their destructive journey and, secondly, forces readers to make sense of this ultimate explosion and the strings of adventures preceding it. Both publications appeared too early on the literary scene to be met with a resounding appreciation; they faded from public life soon after their appearance, be it not without leaving indelible yet irretrievable marks in everything Malay that has been written, read, and discussed ever since.

As a matter of fact, referring to time past, to time present, or to time future, or to all three at once, all written Malay tales have one characteristic in common: they are all ready to explode, just like Claasz's imaginary train - and every act of reading or reciting a tale can be compared to a series of explosions: reading a text rips the strings of its constituent words and sentences apart. Reading, combining the linearity of railroads and the breadth of views in a train window, produces debris of verbal fragments which then forge alliances with debris of other tales, form lines and webs, and sooner or later produce other written tales, which lead to other readings, other performances, different repetitions, and new explosions. One of the intriguing features of Romah asêp $p^{\prime}$ s inconclusive ending is its attempt to summarize what every act of reading Malay tales ultimately is all about: it rips them apart and urges us to move ahead, carrying along shorter and longer resounding fragments, trying to find the knots that are needed to tie them up with other fragments and shape the ever shifting configuration of available tales anew. And in doing so, we reorganize our knowledge of Malay writing again and again, with ever novel retrospective effects. 


\section{Manuscripts and print}

Produced at the instigation of Christian missionaries, printed materials in Malay - both lithographs and typographs - had been wandering around in the archipelago since the seventeenth century, hardly ever interacting with manuscripts and tellers of tales. They had initiated explosions in small circles of readers, these printed books, creating piles of debris that could easily be brought together again in largely similar texts for equally insulated audiences, only gradually expanding. In the first half of the nineteenth century, schoolbooks began to appear to serve the slowly multiplying number of pupils in institutions of formal education, ${ }^{4}$ followed by reproductions of a number of Malay (and Javanese) texts of the 'heritage'; in the second half of the nineteenth century so many Malay texts appeared in the form of periodicals and books in such a great variety of places and circles, with so much differentiation and with such an explosive vitality, that they gained a distinct and prominently visible place within the discursive configuration of Malay as a whole, always on the move. Dramatically and speedily expanding their sway, books and periodicals steadily pushed manuscripts as well as Christian tracts and schoolbooks (many of them reproductions of manuscripts) to the margins of authority in the writing life that has saturated the Malay lands since time immemorial.

Printed materials in Malay generated an erratic energy, activated by the crackling interactions among trains, printing machines, and postal services, introduced by outsiders who thought of themselves as virtual insiders until the Law categorically and repeatedly told them otherwise. Following Dutch and English models, Malay newspapers began to appear in the urban centres of Java in the 1860s. They contained longer and shorter reports and announcements about contemporary events in faraway places and nearby lands; sooner or later tales were added, often in serialized form, Malay interpretations of tales that, just like the information about contemporary events, had their origins elsewhere. In the closing decades of the nineteenth century, printed storybooks in Malay began to appear on Java and beyond, next to the occasional appearance of a manuscript, next to the schoolbooks, newspapers, and books of verse. ${ }^{5}$ Soon more numerous and differentiated than the books

4 Abdullah Abdulkadir's Kitab pada menjatakan dari hal djenis-djenis ilmoe kepandaian orang Eropah (A book on the various sciences and expertise of Europeans) may have been the most incisive Malay textbook in the early days of formal education. First published in Singapore, then in Batavia, it was emulated in other textbooks by authors such as J. Bosscha, H.C. Klinkert, and N. Graafland.

5 See, for example, Kroeskamp (1974), who describes how Malay was initially competing with Javanese, Sundanese and other local languages for authority in matters of reading, without addressing the question to what extent the printed materials from Semarang, Batavia and Soerabaja, from Singapore and Pinang, were mere extensions of schoolbooks and served not 
in other insular languages such as Javanese, Sundanese, and Mandailing, printed materials in Malay were to make long and unusual journeys to faraway places on the Islands as well as on the Peninsula, where Malay newspapers and printed books began to expand their reach but some years later. Most of these early books and periodicals have since vanished from the earth. Not only did they disappear in the material sense, their name and fame were gone before long; however, they must have left intangible traces in conversations as well as in new publications, expanding the heterogeneity of the printed Malay word in inimitable ways.

The Malay books that were produced in Singapore and Pinang - mainly lithographs in the Arabic script called Jawi - were primarily an explosive multiplication of manuscripts. They included repetitions of stories that had long been transmitted by way of manuscripts, as well as reproductions of Middle Eastern and Indian tales, dealing primarily with religious issues. ${ }^{6}$ More directly defying the authority of manuscripts in the Malay lands were the schoolbooks with their novel tales about 'European science' (ilmoe) and 'expertise' (kepandaian) and individual achievements; the serially published books of Malay versions of Chinese tales; and the newspapers with their advertisements and reports about events in the real world. Equally challenging was the book market that developed on the Islands in urban centres such as Batavia, Semarang, Djogjakarta, and Soerabaja, where printed tales were produced that, presented in the 'Dutch' script just like the newspapers, could be characterized as adaptations, transmissions, transformations, or transpositions of Chinese stories: most of them were historical narratives, written in a more or less journalistic style, located some unspecified time ago, somewhere in 'China'. In the welter of printed reports, schoolbooks, tracts, announcements, and storybooks, books of verse also surfaced in which particular events were described in a strictly stylized form. Emulations of socalled sjair - the artfully rhyming core of the Malay tradition - they were also fragmentary repetitions of newspaper reports and stories that people were telling each other in the dead of night about events not so long ago. These were uneasy texts, presenting the world in the stylized form of the past.

only students but also well-read adults. How many older literate people did (and do) actively read printed Malay storybooks at all?

6 See, of course, Ian Proudfoot 1993. There were exceptions to the rule of Jawi on the Peninsula; Chan Kim Boon, for one, published his serialized and illustrated renditions of ancient Chinese tales in the 'European' script which managed to appeal to an audience on the Islands as well (Proudfoot 1993:20-4). Just like their Dutch counterparts on the Islands, the British administrators were in favour of the European script, which they regarded as a sign of 'modernity' and a way to thwart the worrisome impact of writings in Jawi, closely associated with Islam, that hidden force. 
In the 1880s, on Java as well as the Peninsula, the availability of thousands of books was a mind-blowing event indeed in the configuration of Malay discourse, even more so than the appearance of newspapers had been two decades earlier. Given their numbers, these printed texts caused countless explosions. To rephrase this process in more conventional metaphors: the echoes of the hundreds of available manuscripts, scattered over the Islands and the Peninsula, often hidden and protected from the public eye, were drowned out in the debris of the thousands of books that became available in a seemingly endless stream. A new kind of reader emerged, people who knew that more reproducible tales were on their way, in the form not of performances and recitals but of material entities that, like trains roaring through the countryside, invited an active interpretation rather than commanding a casual absorption. The number of readers grew, the number of educational institutions was expanding, and the growth and diversification of book production followed the rules of supply and demand. Books were produced to be sold, and if they failed to create an audience, their producer could be forced to roll up his mats.

It would be hard to construct a detailed picture of the book market in the Malay lands in the late nineteenth century. Books played a minor role in the networks of commercial contacts within Java as well as between Java and the Peninsula. Printing plants were publishing houses, combining the production, publication, and distribution of periodicals with those of books, and producing Dutch, Malay, and Javanese texts on the same presses, with the same typefaces. There were lending libraries where not only manuscripts but also printed materials could be rented for a couple of cents. There were shops, slowly growing in number, in the big cities of Java, Sumatra, and the Peninsula, where books in various languages were available. That is the skeleton of facts that can be deduced from the announcements of Muhammad Said, Muhammad Siraj, Mercantile Press, and Kim Sek Chye Press in Singapore, Lange \& Co, Albrecht \& Rusche, Landsdrukkerij, Kolff \& Co, Van Dorp \& Co, Ogilvie \& Co, and Alex. Regensburg in Batavia, Buning in Djogjakarta, Grimberg \& Co in Soerabaja, and Bisschop, Van Dorp \& Co, Asperen van der Velde, and Yap Goan Ho in Semarang: ${ }^{7}$ at the front or the back of each of their publications, they all printed lists of the Malay (and Dutch and Javanese) books they had for sale, including medical treatises,

7 Obviously, there were other publishing houses, more short-lived. Some houses in the Netherlands and Great Britain also played a role in the book market in Southeast Asia (in particular their more scholarly publications of Malay tales from days of old should be mentioned (prepared for the press by respected scholars such as P.P. Roorda van Eysinga, D. Gerth van Wijk, and H.C. Klinkert) as did mission presses (producing all sorts of texts, operating primarily on the basis of donations rather than following the rules of demand and supply). 
schoolbooks, and books of laws and government regulations. ${ }^{8}$ Some publishing houses had advertisements and reviews of their products published in local newspapers, and some of them occasionally printed separate catalogues of the books they had, ${ }^{9}$ usually a mere list of titles (authors are rarely mentioned) and prices. Such lists were embedded in statements of how books could be acquired: they could be purchased in shops, but interested readers were also offered the possibility of ordering them by mail, paying by postwissel (money order). From these lists and catalogues it can be deduced that printing plants (kantor tjitak) were often operated in combination with a toko or kedai where other commodities were for sale, such as stationery, cigars, and medicines. Printed books could also be acquired elsewhere, among umbrellas, shoes, and other merchandise. And apparently it was not uncommon for a book to be sold more than once.

Judging from the lists and catalogues, books were not really cheap on Java. Books of verse were in the lower price range, usually around $f 1.00 ;{ }^{10}$ books of laws were the most expensive, often more than $f 3.00$; and storybooks in prose were in between. In the 1880s, the latter included predominantly tales about Chinese history, inspired by Chinese tales and composed by peranakan, the term for rather amorphous groups of people who traced their ancestry to foreign and native descent at once, but most often used for those who had Chinese ancestors and held on to some Chinese customs in combination with

8 As early as the 1860s the announcements of Lange \& Co suggest that books of laws were an important source of income and profit: 'Toean Lange \& Co djoega boleh dapat belie soerat Hoekoem ondang-ondang bahasa melaijoe hoeroef Hollanda, jang bergoena atas orang jang memegang poelisie, apa lagie jang melakoekan kaadilan atas tanah Indie Nederland'. Perhaps the publication of Malay books was a peripheral activity for some of them, for Van Dorp, Kolff, and Albrecht \& Rusche, for instance, publishing houses with a large list of non-Malay (mainly Dutch) titles. Interestingly enough, Proudfoot suggests that the main publishers in Singapore tried to make a living from the production and sale of Malay books alone.

9 In Semarang - of course Semarang: the city where intellectual activities were arguably the most intense, the most explosive - an early publisher even commissioned a writer to compose a special poem to introduce recently published Malay books one by one, providing some information about their plots, protagonists, and literary qualities: Ting Sam Sien's Sair adanja boekoe tjerita njang soeda disalin bahasa melajoe (Semarang: Van Asperen van der Velde, 1886). See Salmon 1974, 1981:22-3.

10 There were exceptions, as there always are. In 1891, Sjair Abdoel Moeloek, Radja Barbari was available for no less than $f 3.60$ and Boenga Mawar's Boekoe pantoen penghiboer hati for $f 3.60$, according to the list in Sair dari hal datangnja poetra mahkota keradjaan Roes (Batavia: Albrecht \& Co., 1897). The publishers not only offered for sale the books they themselves had published, but in the same year the same book by Boenga Mawar was offered for the price of $f 0.60$ in the same publishing house's bookshop. Clearly, prices were not necessarily fixed or stable. Another illustration: on one price list Sjair Mida Tjoemboewan was $f$ 0.75, and on another $f$ 1.10. Romah asêp, consisting of two volumes, was listed for $f 3.60$ in one catalogue, in its year of publication, without mention of the author or publisher. 
customs of their native ancestors. ${ }^{11}$ Before long, these Chinese peranakan creations were supplemented with books about other lands, inspired by stories in European languages, initially printed for use mainly in schools, later also for a wider use - and then, around the turn of the century, shorter prose tales about Java and the world began to appear in book form, based on local stories about more or less contemporary events.

Apparently books were meant primarily for people who had some money to spend, regardless of race or ethnicity. ${ }^{12}$ Subtitles, introductions and catalogues suggest that they were meant not only for men, but also for women, ${ }^{13}$ who could be saved from 'boredom', 'anxiety', and 'loneliness' by reading or listening to books, as well as for youngsters 'of all nations', who were 'flying away from the nest' and needed 'guidance in life' and 'entertainment'. However, for lack of concrete data it would be hard to substantiate any general statement about readership or market.

Money could be made in the printing business, it seems, and culture and a name. ${ }^{14}$ The book trade offered ways to act out individual anger, a calling, a conscience, and adventurism. It strengthened awareness of the existence of various languages. It created different frames of mind - and a stronger appreciation of individual activities as well as a sense of the need to search for a communal identity. However, it remains unclear how prominent a role printed materials played in daily life outside the very small circles of literati in urban areas, a civil society being born. The market for newspapers was

11 The term peranakan was also used to refer to those who had European or Arab ancestors, but less often so. The Chinese peranakan men were usually referred to as baba; the same term is used as a form of address in many Malay poems of the time, an indication of the audience they reached. Nona and njonja were used for women of all ethnic groups.

12 Claasz, for instance, suggests in his introduction to Romah asêp that his book is 'useful for all nations' ('aken goena segala bangsa'). The number of active Malay literates in the European script in the Dutch Indies in 1890 was probably no more than a few tens of thousands.

13 See, for instance, the title of Correspondent Hindia Nederland XX's Boekoe tjerita akan mengliboerkan hati bergoena oleh sekalian orang-orang perempoewan dan lelaki jang membatja (Batavia: Van Dorp, 1883) and the coda of Tan Tjhan Hie's Sair ikan (Batavia: Albrecht, 1897) 'toewan dengarken pekir perkata/soerat ini benarlah samata/ baiklah koe batja di dekat palita/ soepaja boleh ditoeroet barang sepata// dengarkanlah he oemat patima!/ / kepada soewami itoe hendaklah rama/beserta bawa baoean di dalem roema/ soepaja bolehlah kekal bersama-sama//'. In his introduction to Boekoe Sin Tjong, Oey Tjoen Bin (1890) explicitly confirms that not only men but 'also women like to read translations of Chinese works'.

14 A penetrating picture of Dutch-speaking and Dutch-writing publishers, editors, and printers in the nineteenth century is sketched in Termorshuizen (2003:102-203) in which their individual wilfulness and courage are evoked, as are their everlasting financial worries, their tense relationships with both the civil administration and the business world, and their ethical drive and fickleness. Until the turn of the century these people also produced many of the Malay publications, and there is no reason to assume that their Chinese colleagues and competitors operated in a different way. The work of publishers was nerve-racking and excruciating in many ways (and still is). 
small and was to remain small. Malay books were of course used in schools ${ }^{15}$ and in religious institutions. ${ }^{16}$ Some people must have treasured a collection of books at home - but the fact that books and newspapers never play a role in printed tales and are hardly ever visible on the numerous family portraits preserved from the late nineteenth century suggests that people did not want to be seen with books and that neither books nor newspapers were items of prestige, prominence, or pride in the way clothes, chairs, flowers, servants, and dogs so visibly were.

How these books - typographs as well as lithographs - were produced involves numerous questions of a technical nature. Some of these questions could be addressed by careful and precise descriptions of the physical qualities of the books, but too few nineteenth-century books have survived climate, indifference, and violence to allow even tentative statements about printing techniques, illustrations, frontispieces, covers, binding, ink, and paper. How printers acquired paper and ink, for instance, is not clear. Decisions about including illustrations and preparing ornamental covers are undocumented. The choice of typefaces is unrecorded. Why books were rarely given a hard cover is hard to explain. And knowledge of how printing machines, crucial in the production of books, made their way across the Islands is still fragmentary. ${ }^{17}$

How writers and editors were rewarded for their labour is another unanswered question, and how copyright conventions were observed is not clear either. As to copyright, relevant regulations were published in Staatsblad voor Nederlandsch-Indië in 1881 (no. 199), but it seems they were designed primarily to monitor Dutch-language publications - only around the turn of the century do references to these regulations begin to appear in Malay texts, meant to warn off possible imitators. ${ }^{18}$ How government censorship worked out for publications in local languages is still unclear, too. The Printing Press Regulations of 1856 'were meant to intimidate and curb the newly emerging press in the Indies'; due to the administration's indifference and ignorance

15 Schools must have been the main outlet for the publications of the Pertjetakan Goewernemen (Landsdrukkerij), which elsewhere had to compete with the products of the larger commercial publishing houses, such as Ogilvie \& Co, Albrecht \& Rusche, and Van Dorp \& Co.

16 On the Islands, mosques and madrasah were the places where publications from faraway places such as Singapore, Pinang and Patani found a market, along with local publications such as the books by Syed Uthman. Christian institutions and schools maintained their own rather closed circuit.

17 Apparently, the machines that were wandering around over the Islands originated from Europe; some of them were acquired by religious groups, others by commercial companies - and they changed hands more than once: sooner or later printers and publishers could be forced to give up their business because they were running out of capital or energy, or because they died.

18 Dilindoengkan dengan hak pengarang Staatsblad taun 1881 No. 199. 
about publications in local languages, 'the transgressions of the vernacular press against Press Regulations [...] may be considered minor' (Adam 1995:15, 52-3). Altogether, the nuts and bolts of the machinery of commercialism, adventurism, and creativity are doomed to remain largely obscure, leaving ever more questions open to speculation. Questions, for instance, of how many copies of books (and newspapers) were printed and how they were stored and distributed. Questions of who effectively owned these tales and poems, these texts and books, and why an author had his creations published by different publishers, ${ }^{19}$ and who was entitled to sell certain ideas, words, books. Could writers be successfully sued for plagiarism, a term that, tellingly, would not have an equivalent in Malay for a long time to come? Why did so many writers use pseudonyms, and why did publishers and printers allow these disguises? And did people, on the brink of modernity, make distinctions between imitation, emulation, transformation, and transposition? And between originality, assimilation, and recollection? The rights, tasks, and obligations of publisher, writer, editor, and printer of Malay books are unclear, in short - but perhaps such questions are not very relevant in a retrospect of Malay writing, too much focused as they are on issues of origin and source than on effects and explosions.

'The author' ${ }^{20}$ as a creative individual claiming to invent novel and original tales on the basis of his personal imagination was a phenomenon as yet unfamiliar in the Malay lands. The commercial activities of publishing and printing were new, and so were the laws and rules that followed in their wake - and clearly there is a link between printing and the emergence of the persona of 'the author'. Perhaps not surprisingly, writers of poetry in particular tended to present themselves as self-aware human beings who worked from personal inspiration; in their books of verse - hardly ever surpassing 64 or 96 pages, stitched and held together by soft covers - they often gave their readers and listeners the personal assurance that they had invented their lines all by themselves and had not been commissioned by anyone; ${ }^{21}$ in many cases they explained their personal acts of writing by describing the anxious loneliness and boredom in which they held their pens and looked at the paper in front of them while embarking on their tormented monologues about the world. Writers of prose rarely displayed a similar self-awareness. They did not indulge in self-gratification and lyrical monologues meant to temporarily soothe an anxious heart and dispel ominous boredom; instead,

19 For example, the publications of Tan Teng Kie and the anonymous serial of Graaf de Monte Cristo.

20 It is worth mentioning that female authors were very rare until much later.

21 Numerous are the echoes of poetic phrases such as 'mengarang sendiri dengan pikiran/ doedoek menoelis dengan kesabaran/sobat batja djangan kagoesaran' (Tan Teng Kie 1898). 
they usually added a separate introduction to their tales so as to make sure that their words engaged their readers and their sentences retained their power of dialogue. Malay writing should keep moving and shifting - and all too often the stylized monologues of poems tend to halt these movements.

\section{A poem of trains}

At the end of his Sja'ir djalanan kreta api (The poem of the railroad line), a book in verse about the construction of a rail line in West Java, Tan Teng Kie gives a long description of the work of his publisher, Alex. Regensburg, in Batavia. Toewan Regensburg did his work very conscientiously, Tan assures his audience in rhythmical and rhyming Malay, and he was unequalled in this world. Many were his products meant to 'please' and 'soothe' readers in the 'land of Hindia' as well as 'to open their hearts to the secrets of the sciences'. And the typographers too did excellent work (see also Salmon 1988). To Tan's 22 pages of verse, Alex. Regensburg himself added a page-long advertisement in which readers are told what his enterprise, named Regina Orientis, was all about ${ }^{22}$ - and the fact that this text is in Dutch $^{23}$ and that some verses in the final pages of the main text are half in Dutch, half in Malay ${ }^{24}$ could be the beginning of another tale, one about the linguistic situation in urban centres and about the readership of books in verse such as Sja'ir djalanan kreta api: it obviously addresses 'people of all nations' who shared an active knowledge of several languages at once or, perhaps more precisely, of several forms of a single language.

Concrete acts of reading in Batavia, Semarang, Singapore, and Soerabaja remain something we do not know much about. And so does the life of newspapers. And so does literary life, another feature of acting and speaking modern, the framework of nationalism and fiction in the Malay lands, penetrated by printed books, anxiety, electricity, and trains.

22 Perhaps a commercial enterprise such as Regina Orientis was too specialized, but even when it expanded its business by offering all sorts of printing services (see the advertisement in Regensburg's own creation Hikayat roh manoesia (1893), the firm had difficulty surviving. Apparently, the sale of stationery did not save Regensburg, 'who was unequaled in this world'; he had to close shop, a fate he shared with others who tried their luck (and money).

23 Regina Orientis - Uitgeverskantoor hoofdzakelijk voor Oostersche Literatuur. Aan dit instituut zijn verbonden Een eigen inrichting voor Boek- \& Steendruk, Een eigen boekbinderij alsmede Een Speciaal Kantoor voor Maleische Translaten en Interpretatien, dat wil zeggen Een Maleisch translaatkantoor met nauwkeurig afgebakenden werkkring. Alex. Regensburg. Senen 563 Batavia.

24 For example, 'djika koe'ingat, dengan menjapoe 'n traan/ terugzie op de afgelegde spoorwegbaan/ boleh di kataken 'reeds veel gedaan' / kendati met stoom is 't niet gegaan//'. 
Trains. ${ }^{25}$ Tan Teng Kie's Sja'ir djalanan kreta api is intriguing because of its subject matter, so seldom explored in nineteenth-century Malay print, but also because of its author's struggle in defining his stance on novelties (summarized before long in the Malay lands by the terms modern, kemadjoean, and kepandean). The artfully rhyming and rhythmical verses steer readers to the anonymous tradition, to the voice of recital, to days of yore. They also foreground the writer himself, who claims he witnessed the railroad's construction with his own eyes, like a true journalist, and knew some of the Dutch and Chinese people involved in this new adventure. Written in praise of the new machine, Sja'ir djalanan made its readers aware of the power of imagination, science, and human agency, but its delight in material achievements and commercial prospects is tempered by anxiety, expressed in uneasy phrases such as menjapoe ' $n$ traan. Trains, Tan told his audience, were a blessing for the local populace (and for Chinese businessmen in particular) in terms of labour and money, but they also brought misery: during the construction of the railroad one worker was killed, others were wounded in a series of accidents, and once the trains started to run, some people were hit or almost hit - and the introduction of guards and fences did not make people happy either. Perhaps trains were not harbingers of awesome excitement and profit alone. Perhaps European machines and expertise were to bring more than progress, possibility, and happiness.

Since days of yore, Malay authors had demonstrated a sense of proportion and distance, and Tan Teng Kie's work with its delight and its tears is carried by this voice of irony: the train is a great invention, yes, opening the way to all sorts of new feelings and future experiences, but laying rails creates plenty of problems - and trains cause accidents and take control over people's lives. Every bright side has a dark side - and life without colonial interventions, without money and trains, without a future, was perhaps not so bad after all. And are sjair not supposed to evoke the beauty of the past?

\section{Beyond the train}

The virtual silence about trains in Malay writing as well as Tan's ambivalent yet artful evocation of railroads suggests that the Malay lands harboured indifference and doubt about the importance of trains - and, more generally, about the experience of machines and kemadjoean. The explicit dismissal of railroads, summarized by the statement that riding on a train, for the indi-

25 The first trains on Java appeared around Semarang in 1870, followed by other train lines, between Batavia and Buitenzorg (opened in 1873), between Batavia and Tjiandjoer (1883). In 1894 the connection between Batavia and Soerabaja was completed. 
vidual traveller, is like 'a punishment for an innocent man' in Claasz's (1895) tale Romah asêp (Stoomhuis) (The Steamhouse (Stoomhuis)) may have served Malay readers and listeners as an explicit reminder that they should not be too excited and delighted about the ever approaching future - and that they should give second thought to life after the introduction of trains. Perhaps this dismissal is even more effective because it is expressed by a European, an expert in novelties and science, that is. He speaks in Malay about India, a region which in the Malay lands was still floating between a Never-Never Land identity and a faraway reality, to be explored in Malay endeavours to make more sense of the outside world.

'A punishment for an innocent man' is the observation of Maucler, a man who is looking back on his nightmarish train ride from Bombay to Calcutta. 'We are blinded by smoke, steam and dust', he tells his European friends while Indian servants are watching, 'and even more so by the vehicle's speed. We are locked up in a little box, and we can hardly see anything through the little window'; 'now and then we make a stop at a station that looks just like the last one and the next one', and 'the only thing we see of the cities we pass through are their walls'. And then that awesome noise! ${ }^{26}$

Maucler's scathing denunciation of trains is the beginning of a realistic - that is to say, journalistic or travelogue-like - tale that later pundits were to call, rightly or wrongly, a predecessor of science fiction stories: strong and sturdy heroes make an adventurous, open-ended journey in an as yet imaginary vehicle, a marvel of technological achievement, through a real landscape.

For their journey, Romah asêp's British heroes make use of a machine which, Claasz seems to suggest, could serve as a substitute for the accursed train in the future: an elephant of iron that, driven by steam, is able to pull two-wheeled carriages in the shape of pagodas through every form of nature with considerable speed. The carriages are like a utopian place, equipped with every possible comfort: a dining room, a bedroom for each of the travellers, a kitchen, a library, and some very faithful Indian servants. The 'steamhouse' (romah asêp) or 'iron monster' (raksasa besi) is clearly preferable to the train that is dismissed in the tale's beginning - and it is so comfortable in

26 '[T] oleh leboe terlebih oleh tjepatnja naekan. [...] kaloe orang tertoetoep di dalem kotakan kreta, tiada bisa liat lebih dari lebarnja lobangan tjandela troos berdjalan siangari malem, santernja rata rata 10 mijl di dalem satoe djam, dengan naek toeroen goenoeng masoek dan keloewar lobangan didalem goenoeng bertemen tikoes dan landak, tjoema boleh brenti di mana station sabentar jang semoea sama roepanja, tjoema satoe tempo bisa liat timbok nja kota, dengen sedjalan djalan moesti mendingarken soewara roesoeh dan panjoeling nja kreta api mendjeritnja rail jang terlindes roda, apa itoe kaoe boleh bilang perdjalanan dengan meliat? Kita rasa itoe terhoekoem dengen tiada berdosa.' (Claasz 1895:9-10.) 
itself that the travellers are hardly ever tempted to look outside. The vehicle - it acts like a tank or, even more futuristic, like a cyborg - impresses not only the passengers but also the local people who, Maucler reports, pay homage to what they see as a divine being and have themselves willingly run over by it. The steamhouse seems to protect the travellers from the real world; and only when they leave its comfortable security do they catch a glimpse or two of local culture and nature - and such outings usually expose them to anxious adventures and problems.

To make an explosive shortcut to the future, the iron monster, the train's imaginary successor, does not survive the journey: one of its pagodas is lost when it is attacked by a herd of elephants of flesh and blood, and the rest of the monster explodes when the European travellers are attacked by a group of followers of the Indian prince Nana Sahib. Romah asêp is a confusingly different tale because it does not deal with the adventurous love between a man and a woman or the lack thereof (as Malay tales were wont to do), but rather with the camaraderie among men or the lack thereof, moved ahead by a machine and a feud between a British colonel and an Indian prince - and eventually the monster and the feud evaporate in an open-ended 'bang!!'. Romah asêp is a complicated, multivocal narrative if only because the perspective from which events are told shifts between Maucler's and an omniscient narrator's. It is a sinister tale because of its explosive ending, which should remind us of the act of reading: the adventures of an imaginary machine that replaces the train and the subsequent dissemination of its constituent elements in an explosion are like a tale which moves the reader from a vague beginning to a disintegrating end - and the future will end in a bang again, like every novel act of reading does.

Romah asêp (Stoomhuis); Satoe tjarita dari toean Jules Verne: Tertjaritaken di dalem bahasa Melaijoe renda oleh W.N.J.G. Claasz, ambtenaar pensioen (Steamhouse (Stoomhuis); A tale by Mr Jules Verne: Told in Low Malay by W.N.J.G. Claasz, retired government official), says the cover of the book. Under this verbal announcement is a picture of an elephant, its trunk triumphantly raised. The text's title (in which Verne's name figures prominently) is printed in larger letters than the author's name, W.N.J.G. Claasz: obviously the anonymity of tradition and beginnings is challenged here, another sign of the arrival of modernity in the Malay lands. ${ }^{27}$

27 But then, on second thought, even in the context of 'tradition' and 'heritage' - retrospective terms that were created to refer to tales and manuscripts that travelled around in the Malay lands and held people together - the term 'anonymity' may be inappropriate if not irrelevant: the people who recited from and listened to tales of old usually knew who had written and performed them before; moreover, it was not the writer but the tale that was important; writers were people with a pen presenting themselves as mere mediators in the repetitive transmission of words about a timeless world. 
Romah asêp was certainly not the first printed Malay tale allegedly modelled on a tale in another language. Ting Sam Sien's rhymed booklist of 1886, Sair adanja boekoe tjerita njang soeda disalin bahasa Melajoe (Salmon 1974), shows that a large number of books based on Chinese tales had already been wandering through the Malay lands for ten years when Claasz's book appeared. Most of these tales had been published in instalments, ${ }^{28}$ following the serial spirit of Malay newspapers, which printed renditions of Javanese, Chinese, and Dutch tales in between advertisements and reports of contemporary events. This very disjunctive serialization made them not only commercially rewarding - readers, curious to know what would happen next, were forced to buy the next instalment - but also literarily intriguing: they were fragmentary, and these fragments, episodes, chapters seemed highly interchangeable, if not forgettable - and yet not really. Conversely, this drive for fragmentariness in instalments explains the selection of tales that were regarded worthy of serialization and emulation in book form: not dense and coherent Bildungsroman but loosely organized tales of adventure, far away and long ago. Not depth but breadth: in novel forms these tales perpetuated the Malay tradition of travel narratives, which potentially provided Malayspeaking communities with knowledge about faraway countries and ways of life in days of yore. ${ }^{29}$

'China' seemed like an inexhaustible source for these novel Malay tales of adventure. In retrospect, the wave of Malay books about China and its history that were published in Semarang and elsewhere in the 1880s was strong enough to develop the contours of a separate literary life, gaining momentum through their dialogic competition with manuscript-inspired tales that perpetuated the Malay past as well as tales that were modelled on European tales. ${ }^{30}$ As for the latter, Romah asêp had been preceded by the serial publication of, for instance, Graaf de Monte-Cristo; Karangannja Alexander Dumas: Tjeritaken dalam bah. Melajoe rendah dengan menoeroet djalan jang gampang, by an anonymous writer; 31 by the equally anonymous (and voluminous) Barang rahsia dari istana Konstantinopel; Riwajat waktoe sekarang; 32 and by G. Francis's Hikajat 1001 malam

\footnotetext{
28 The same holds for the Malay texts in European script that were printed in Singapore.

29 See Quinn's intriguing remarks (1992:4-8) about nineteenth-century Javanese travelogues.

30 There are some precursors to the Malay tales published in book form in the early 1890s, such as the enigmatic Lawah-lawah merah, a 'novel' published in the 1870s that was equally inspired by a European tale (Salmon 1979). Far more important in this connection is that most of these China-based tales were apparently Malay renditions of Chinese tales.

31 Tradition has it that F. Wiggers and Lie Kim Hok made the adventures of the Count of Monte Cristo accessible to Malay readers on the Islands; started in 1894 by Karsseboom \& Co, the serial of 25 volumes was not finished until 1899 by Albrecht \& Co.

32 Based on a serial in Bintang Barat in 1880, it consisted of 21 volumes produced over a period of seven years (1892-99) by Albrecht \& Rusche, Batavia-Solo.
} 
ja-itoe tjeritera-tjeritera Arab, ${ }^{33}$ also published in instalments. ${ }^{34}$ And, of course, by the work of A.F. Von Dewall, ${ }^{35}$ who started his writing career with Hikajat Robinson Crusoe; Terkarang pada bahasa Melajoe (1875), ${ }^{36}$ Kesah pelajaran Nachoda Bontekoe; Terkarang pada bahasa Melajoe dengan mengikoet bahasa Wolanda (1876), and Kesah pelajaran seorang perampoewan, jaitoe Ida Pfeiffer mengoelilingi boemi $(1878)^{37}$ - and in retrospect Von Dewall should perhaps be given a central role in the emergence of 'modern Malay literature'.

Hikajat Robinson Crusoe is a fine example of how a tale could be presented as an original and novel Malay tale: its cover told contemporary readers that Von Dewall was its author, and for the time being only highly literate people in the Indies, knowing that the tale about Robinson Crusoe was a creation of Daniel Defoe (but how many really did know this?), would have been willing to argue that although Von Dewall may have been a writer, he certainly was not an author. The hundreds of copies were used primarily at schools, it seems, and Hikajat Robinson Crusoe went through various editions in the very years that authorship was becoming an issue. In later editions the cover wording was changed: Hikajat Robinson Crusoe was now 'following a Dutch text' (dengan mengikoet karangan bahasa Wolanda), another statement that may have made the more sophisticated readers in the Indies frown. ${ }^{38}$ The same subtitle, mengikoet karangan bahasa Wolanda, was added to many of the tales published in Malay newspapers, as if the fact that their beginnings as a French, German, or English 'original' could be ignored and only Dutch texts played an active role in the formation of Malay literary life. References to masterly Dutch models may have been more viable commercially and culturally; moreover, they may have been regarded as a way to protect the publisher from possible censorship, always lurking around the corner. The explicit appropriation of

33 Disalin kepada behasa Melajoe, dengan menoeroet karangan toean Gerard Keller di dalam behasa Olanda (Batavia:Albrecht \& Rusche, 1891-94).

34 Many of the Chinese tales were also published in instalments, some of them extending to 800 pages.

35 He was a son of H. Von Dewall, whom the government in Batavia had sent to Riau to collect materials for a standard Malay grammar and for Malay-Dutch and Dutch-Malay dictionaries (Van der Putten 1995).

36 Published by Landsdrukkerij (Pertjetakan Goewernemen) in Batavia (Bandar Batawi).

37 First published by Ogilvie in Batavia and by Van Dorp in Batavia, respectively. It is worth mentioning that all three of them are tales of travel: they read like a form of resistance to the intrusion of elements of European knowledge (see Quinn 1992:5).

38 Hikayat Si Saridin is a similar case: after a first anonymous edition (Si-Saridin) and a second edition (1876) which refers to F.K. Voorneman and D. Gerth van Wijk, later editions make mention only of Gerth van Wijk as the 'author' - and this silence raises the judicious question of who is responsible for it, obviously a core question in matters of copyright; corresponding questions could be raised in connection with the anonymous Boekoe tjerita-an hikajatnja Baron van Munchhausen; Tersalin bahasa Melajoe (Soerabaja: Grimberg, 1890), which was apparently inspired by an anonymous Dutch translation of a German original. The history of translations is a complicated one. 
elements from Dutch texts also had a political effect in that Malay printing showed that not only 'China' but also 'Holland' and 'Europe' were interesting lands where people, eager to leave the coconut-shell isolation of their village for a new society, could acquire information about the world at large. Subsequent developments were to show that tales after Chinese models provided their readers with ideas of a Chinese identity, creating debris that, in the web of Malay writing, coagulated into distinctly Chinese threads, which did not necessarily concur or concatenate with the threads created by the debris of Europe-inspired tales: there were dialogues, conflicts, and tensions among Malay texts, as there are in the writing life of every discursive configuration, ever expanding and contracting. The number of Malay tales was growing, and they all competed for attention, commemoration, and authority. Reading them initiated explosions, conversations, and discussions that led to other tales, to conflicting ways of making sense of contemporaneous life, identity, and society. They all were publications that deserve a place in any survey - inconclusive by definition - of Malay writing.

It is tempting to interpret this resistance to mentioning sources and beginnings in terms of the continuation of the Malay manuscript tradition in which, through the ages, numerous Sanskrit, Arabic, Persian, Javanese, Thai, and Tamil works had been incorporated and emulated without the slightest reference to origins and interactions. 'Transposition' or 'transformation' could be used as a comprehensive term for these complicated intertextual and interlingual processes of reproduction (Derrida 1985:165-208) - but the laws and regulations introduced towards the end of the nineteenth century to control the expanding stream of printed materials were to shatter every form of comprehensiveness. Until the 1880s, the multifarious acts of transposition had been covered by the Malay word salin ${ }^{39}$ in the explosions in Semarang, Batavia, Singapore, and Soerabaja the reach of salin began to dwindle, from the acts of 'transforming' to 'translating' and 'adapting', and then to 'copying' alone, in the process leaving space for new words to differentiate the various forms of Malay writing - and eventually making the act of translation a distinctly secondary activity, of little relevance and effect in literary life.

In every act of writing and reading, memory is combined with experience, repetition with performativity. In the newly emerging Malay literary life, these combinations were looking for a new balance in an atmosphere of growing anxiety as the tensions between personal experience, performativity, memory, and repetitions had never been stronger ${ }^{40}$ and individual agency became intertwined with notions of imagination, origin, and originality.

39 Apart from salin, other words were used as well: rubah, turun, ganti, melajoekan, olah, ikut.

40 Tan Tjhan Hie, who prepared a new edition of Sair ikan in 1897, tells 'my readers' in the preface that he transformed (salin) Mohamad Hasan's Sair ikan from Jawi script to European script 
Romah asêp; Tjaritaan dari toean Jules Verne. It was not the first time the name Jules Verne had appeared in Java on a book cover. In 1889, Jules Verne, Hikajat Piliyas Pog - tjarijosipoen tijang totohan sagah angubengi doenya ing dalem 80 dinten lame-lamenipoen, mawi gambar 53 idji had been published by A. Bisschop in Semarang; it was a Javanese text, 'Javanized' (kedjawekaken) by L.Th.M., ${ }^{41}$ who also prepared a Malay version, Hikajat Fileas Fogg atawa mengoelilingi boemi dalem 80 hari lamanja; Menoeroet persalinannja tjara wlanda dan tjerita asli jang tertoelis dalem bahasa Fransman oleh toewan Jules Verne. ${ }^{42}$ It was not the first time either that Verne's work had been used in a Malay text: in 1886 Lie Kim Hok had already combined elements of Jacob van Lennep's novel Klaasje Zevenster with elements of Jules Verne's Tribulations d'un Chinois en Chine, resulting in Thjiat Liap Seng, (Bintang Toedjoeh), Tjerita di negeri Tjina pada djeman Karadjaan Taij Tjheng Tiauw, Maha Radja Ham Hong. ${ }^{43}$ Obviously, knowledge of Verne's work had reached the Indies, ${ }^{44}$ and some publishers must have thought that his tales were strong, fragmentary, and adventurous enough to warrant their incorporation into Malay writing. Money could be made from them - and they could give the growing audience of readers useful knowledge and entertainment.

\section{Counterpoints}

1895 turned out to be an explosive year for 'Jules Verne' on Java. In one year, the name was newly printed on the covers of at least six Malay publications,

\footnotetext{
('saja salinkan karangan itoe dengan hoeroef Ollanda ini'); closer comparison suggests that this is not (yet) a case of one-to-one transliteration: the Sair was given novel possibilities of meaning by adding and omitting phrases. The anonymous writer of Sjair Tan Sha-Go Nio (1896) in Almanak Melajoe gave salin a wider meaning: 'denger lah sobat ini rentjana/dapet menjalin di boekoe tjina/kerna di timbang amat bergoena/ pada sekalian baba dan nona'. Regensburg goes one step further and explicitly problematizes the term salin in his introduction to Sja'ir Midah Tjoemboewan, tersalin dari pada hoeroef 'arab serta di sahken karangannja (Batavia: Regensburg, 1890): 'bahwa kitabkoe ini ijalah salinan dari pada soewatoe kitab toelisan tertoelis dengan hoeroef 'Arab. Adapoen kitab toelisan jang telah di salin itoe njatalah boekan asal melajinken salinan. Aken sekarang asalnja karangan itoe manakah dija, dan sijapa jang mengarang dija? Wa'llahoe a'lam!'

41 The initials of L.Th. Maijer, a prolific writer of Dutch books on Javanese subjects as well as a Malay writer/translator of legal texts.

42 Published by Van Dorp in Semarang in 1890.

43 Batavia-Bogor, 1886-87, 8 volumes. Verne's works were never reproduced by the presses of the Landsdrukkerij, one of the most authoritative publishing houses in the Indies which, tellingly, never published a book with a Chinese background either.

44 'In particular French novelettes were very popular. Towards the end of the 1870s people could buy them in the stores (toko) of Van Dorp and Kolff in Semarang which [...] offered a considerable selection of them, regularly replenished. Not only the work of authors such as Xavier de Montepin, Eugene Sue, Jules Verne, and Victor Hugo was available in these places, but also the work of Daudet, Flaubert, Edmond de Goncourt, and Zola.' (Termorshuizen 1988:146.)
} 
published in Semarang by the respected publisher/printer G.C.T. van Dorp. Romah asêp, in two parts, was the first of a serial, followed by 20.000 mijl di dalem laut; Tjaritaän dari Jules Verne: Tertjaritaken di dalem bahasa Melaijoe renda oleh W.N.J.G. Claasz, in two parts, and Poeloe rasia; Tjaritaänja dari Jules Verne: Tertjaritaken di dalem bahasa Melaijoe renda oleh W.N.J.G. Claasz, in two parts. One year later, the publisher/printer Tjiong Eng Lok in Batavia followed suit, issuing Jules Verne - Michael Strogoff; Djoeroe pembawa soerat dari Baginda Czaar Rusland: Tersalin di dalem bahasa Melajoe rendah oleh M.C.

Who was the owner of Romah asêp? In the Malay lands, printer, publisher, editor, and translator could still pretend not to understand that question - and it appears most of them preferred to ignore it. The laws of 1856 and 1881 had not really dealt with the issue of copyright once and for all; the cases of what, in legal terms, could be called 'plagiarism' or 'imitation' were many, not only with regard to books but also to serials and articles in newspapers, ${ }^{45}$ but there is no memory of a case in which such 'equivocality' (saboenji) was effectively brought to trial. For Van Dorp and Claasz the ownership of a Malay tale was not an issue. However, for Tjiong Eng Lok it apparently was: in his publication of M.C.'s Malay transformation of Verne's Michael Strogoff he added, facing the front page, a warning: 'to make known that everyone who buys this book is asked to look on page 163 where there is a stamp and a signature of the publisher' - and on page 163 readers were told: 'everyone who distributes equivocal books will be brought to justice if they are not signed Batavia, 24 December $1896^{\prime}$, and under this phrase appeared Tjiong's signature. ${ }^{46}$ That was a clear gesture - and in these years similar warnings began to appear in other printed Malay books as well. Tjiong's efforts to protect his products show a growing awareness of the need to distinguish between original and translation, between intervention and imitation, between creativity and copying.

For a while, the excitement of these novel experiences in the world of print, copyright, money, and machines was shared by speakers of Malay and speakers of other languages, that is, of 'various nations' (bangsa), in Semarang and elsewhere. They would have become a central feature in a shared 'structure of feeling ${ }^{\prime 47}$ in the Indies had the Dutch masters not imposed legal and hence socio-cultural distinctions between 'natives', 'Chinese', and 'Europeans'.

45 In this very grey area of pretended ignorance and wilful silence Malay literary life emerged, concurrent with notions of fiction, factuality, fantasy, and imagination, embedded in the expanding configuration of trains, electricity, printing presses, and postal services. Studies such as Davis 1983 suggest that a literary life could emerge along the same lines in every linguistic community.

46 '[M]embrie tahoe barang siapa jang bli ini boekoe di harep pereksa pada moeka lembaran No 163 dimana itoe ada satoe Tjap dan tanda tangan dari jang mengeloearkan boekoe ini' and 'Barang siapa iang menjiarkan kitab-kitab iang saboenji dengen ini, nanti ditoentoet di hadepan pengadilan, djikaloe ini tida tertanda oleh Batavia 24 december 1896'.

47 The term is Raymond Williams's (1977:128-35). 
Such distinctions steered these exciting experiences of communality towards fragmentation before they could gain sufficient momentum and create a sense of coherence in Indies society. 'Foreign Orientals', 'natives', and 'Europeans' were different, the Law proclaimed, and hence they were supposed to operate in different spheres, different 'languages', different forms of writing, in which ideas about trains and explosions as well as notions of copyright and ownership were played out differently.

Most of Von Dewall's books were printed in 'Dutch script' (toelisan Wolanda), just like the Malay newspapers of Java. By doing this, Pertjetakan Goewernemen (Landsdrukkerij) confirmed the readerly differences that were developing between the Peninsula and the Islands, the effect of the use of different scripts and separate circuits of exchange. ${ }^{48}$ The differences could only be deepened by the fact that Von Dewall's creations were widely used as textbooks in the Islands' schools, ${ }^{49}$ institutions that are important screws in the machinery of control and comprehension which every administration uses to impose standards and differentiations. In terms not only of its script but also of its content, Robinson Crusoe was a counterpoint in the configuration of Malay writing. ${ }^{50}$ In terms of its language, however, it called up the days of old: the Malay that Von Dewall used in Hikajat Robinson Crusoe and its successors - vocabulary, syntax, phrases - contained strong echoes of the tales that were preserved in manuscripts everywhere in the Malay lands on both sides of the Strait of Malacca, including Singapore.

48 Most of the Malay schoolbooks used on the Islands since the fragmentary introduction of formal education in the 1830s had been printed in 'Dutch writing', steering readers away from Jawi writing, which the administration saw as a vehicle of Islamic teachings and thus undesirable. Moreover, 'Dutch writing' was commercially more rewarding and practical, as the same presses and typefaces could be used for books in Dutch, a half-hearted attempt at making the most important languages of Java (Dutch, Malay, and Javanese) permeate each other and, in the future, perhaps converge.

49 Hikajat Robinson Crusoe was followed by, among others, Hikajat Sinbad, Hikajat Aladin, Hikajat Indera Bangsawan, and Hikajat Masjoedoe'lhak, the latter two explicitly presenting themselves as being 'adapted from a number of manuscripts'; some of Von Dewall's publications were in Jawi, some of them were printed by commercial publishing houses rather than by the government's Landsdrukkerij. Most Malay schoolbooks used on the Islands contain considerably more echoes of phrases and sentences of manuscripts than of colloquial speech and newspapers, thus laying the foundations of a conflict between high culture and low culture.

50 Von Dewall's Hikajat Robinson Crusoe was allegedly modelled on a Dutch translation of the German version of Defoe's novel Robinson Crusoe. For a comparison of Defoe's novel with Von Dewall's creation, see Jedamski 2002:25-30; the Malay version is in many ways different from Defoe's original: the relationship between Crusoe and Friday is one of teacher-pupil, for instance; the English tale's praise of individualism is softened by the foregrounding of Allah's guidance; and the first-person singular narrator of the English version is replaced by a third-person perspective. Such differences show that 'translations' are always a site of competing voices where writers are struggling with perspectives, omniscience, and subject positions that the two languages involved seem to offer. 
Romah asêp, too, was printed in 'Dutch script' - and therefore it was equally inaccessible to most Malay readers on the Peninsula, and equally unsuitable for the book market in Singapore and Pinang. In terms of language, however, Claasz's book was radically different not only from every Jawi publication but also from Von Dewall's creations. It was composed in Melajoe rendah ('Low Malay'), and not in the stylized Malay of days of yore that Von Dewall perpetuated in his work, suggesting the strength of continuity and memory. As such, Romah asêp could be seen as another strong counterpoint in Malay writing, soliciting explosions that, unlike those of Von Dewall's publications, could be connected in a negative sense with tradition, past, and memory; it pointed, instead, to the unknown future.

In the late nineteenth century, the term Melajoe rendah was used to refer to forms of Malay that echoed urban conversations and periodicals on Java rather than Sulalat as-Salatin, Hikajat Hang Toeah, Hikajat Robinson Crusoe, and conversations in the Malay lands of Sumatra and the Peninsula. Selfproclaimed experts of culture, Claasz's European contemporaries, tended to picture Melajoe rendah as 'the language of communication' on Java, in particular as the language that accommodated Europeans, Chinese, Arabs, and other outsiders. 'Low Malay', the colonial masters stated, did not have a core or a basis, and it was not strong enough to provide its users with a distinct identity or culture; slowly but surely this derogatory characterization became the accepted wisdom among literati in the Malay lands, to be taken up as a name of honour by some of them, as an invitation to renunciation by others. The derogation of 'Low Malay' ${ }^{51}$ was supplemented by the claim that so-called Riau Malay was the superior form of Malay, 'High Malay'52 and already before the turn of the century the administration in Batavia, caught in the vicious circle of associating lowness and casualness with chaos, subversion, and danger, began to pursue an active policy of promoting 'High Malay' as the standard to be used in administration and education. Echoes of Von Dewall's words and sentences, loud and visible, were to be refracted by Ch.A. van Ophuijsen in his Malay spelling book and grammar which, in their turn, were to be major points of calibration in the development of so-called 'modern' forms of Malay in the Dutch Indies and, later, Indonesia.

Occasionally, 'Low Malay' - Melayu rendah - was still presented in a positive way. The Batavian publisher Karsseboom, for instance, added a subtitle to Graaf de Monte-Cristo; Karanganja Alexander Dumas: Tjeritaken dalam bah.

51 Indicative of its flexibility and openness, the spelling of the Malay term varied: Malajoe rendah, Melajoe rendah, Melajoe renda.

52 It is perhaps superfluous to point out that this low opinion of Melajoe rendah is based on several fallacies. Malay of Riau (Melajoe tinggi) was not necessarily higher or more authentic than the forms of Malay used in the urban areas of Java; the term Melajoe rendah is a dangerously simplistic summary of a very heterogeneous set of discursive forms with ever shifting and moving identities. 
Melajoe rendah dengan menoeroet djalan jang gampang (1894). 'The easy way' (djalan jang gampang) suggests familiarity and informality, and these were the very features publishers such as Karsseboom and Van Dorp, in search of profit and respect, were exploring: the readership should be as wide and varied as possible. Publications in 'Low Malay' were intended for people of all nations indeed, in support of a very flexible if not frivolous and open-ended language which, close to the ever shifting spoken forms of Malay, was in a constant process of shaping a shared identity for 'all nations' - and its failure to gain the upper hand over publications in 'High Malay' for the central place in literary life led, in the long run, to the creation of an enduring conflict between 'high culture' and 'low culture', first in the Indies and then in Indonesia.

Printing Malay, in short, was bound to give rise to notions of standard and norm, steering writers and speakers towards a homogenization which has severely disrupted the vitality and volatility of the Malay discursive formation on the Islands up until the present day. ${ }^{53}$ It may have strengthened the identity of a 'Malay nation', yet it also closed the door to 'other' worlds where things are done in unfamiliar yet imitable ways.

\section{Claasz and Romah asêp}

Following the writerly conventions of the day, Claasz explains his intentions to his readers in a one-page introduction. 'I tell this story,' he states, 'in the Malay that is generally used everywhere in the land of Java, hoping that it will make a contribution to lively discussions and, moreover, stimulate the search for expertise'. ${ }^{54}$

'The story should lead to conversations and expertise' was to be the explicitly worded purpose of many Malay books to come. And Romah asêp was strong enough to provoke conversations among its readers. About the use of miraculous and imaginary machines and the expertise needed for making trains. About the land of India and its religions. About British skills and science, about violence and explosions, about the audacity of Indians in confronting Europeans. About the importance of individual agency. About the open future. And Claasz's descriptions of the ways British travellers treat

53 An equally disruptive centralizing energy took hold of the written forms of Malay on the Peninsula once the 'European script' was substituted for Jawi in the 1950s.

54 Maka tiada lah saija memboewat tjaritaan ini, dengan menganggep di dalem ati aken memboekaken kapinteran, meskipoen di dalem bahasa melaijoe, meskipoen di dalem tjarakarangan soerat atawa kepandaian menjalin bahasa itoe tiada; hanja tiada lain saija menjaritaken hikaijat ini di dalem bahasa melaijoe, jang teroemoem terpake di anteiro tanah Java, dengen pengarepan soepaija mendjadi pasoembang ramenja ommongan dan tambahnja menjampeken pentjarian hal kepandean. 
the local populace and the ways the Indian hero, Nana Sahib, challenges British prowess must have found some resonance in the hearts of readers on Java, in ways the Dutch masters were unable to fathom and probably did not even notice until later. The debris of Romah asêp must have made some of its readers aware of the force of individual acts of resistance as well as of its counterpart, the volatility of colonial authority - and these readers were probably not only those who had learned to read and write from Von Dewall's books with their conclusive endings.

Claasz added a second introduction to his book, in which he informs his readers that Romah asêp is the first part of a serial: 'the story that is being told is like the beginning of a story of the adventures of two princes in Hindustan during the great war between the British and the Hindus in 1857-1867'. ${ }^{55}$ Connecting the three tales or the six books and suggesting that a relative of Nana Sahib, the main Indian hero in Romah asêp, was to appear in 20.000 mijl di dalem laut as well as in Poeloe rasia ${ }^{56}$ was a clever marketing strategy: people were made curious and anxious to purchase the next and previous instalments about these Indian heroes. These were meant to be fragmentary tales, sets of adventurous episodes, and on the budding Malay book market readers could appreciate these episodes in various sequences, omissions and all. Connecting episodes and fragments required creativity, and Malay readers must have enjoyed the liberty these serialized tales gave them to use their imagination to make sense of them in disjunctive and fragmentary conversations. Indeed, Romah asêp was a truly Malay tale right from the beginning.

In his introduction, Claasz writes that Mr Verne was knowledgeable 'in various sciences' and that his tales contain some 'good illustrations and lessons, useful for all nations, and even more useful for a person who wants to apply scientific knowledge and other expertise'.$^{57}$ That was the road Malay

55 Hal hikaijat jang di tjaritaken ini ja itoe seperti satoe permoelaian dari hikaijat hal pendjalananija doea Pangeran poetra Radja di Hindoestan, sekala prang besar antaranja bangsa Inggris sama bangsa Hindoe, sedjalan taoon 1857 sampe 1867 [...] sehabisnja tjaritaan Romah Asep ini jang terbegi di dalem doea djilidan, adalah toeroetanja hal pendjalananja Pangeran itoe, jang di tjaritaken di dalem hikaijat 20000 mijl di dalem laoet, djoega terbagi dalam doea djilidan; dan sateroosnja lagi sampai pengabisanja hal pangeran itoe, di tjaritaken di dalem hikaijat Poeloe rasia terbagi djoega di dalem doea djilidan.

56 In real life Nana Sahib was one of the leaders of the Indian Mutiny of 1857. He vanished after the Mutiny failed to gain momentum. In Verne's Vingt mille lieues sous les mers; Tour du monde sous-marin (1866) Nana Sahib's ally, Prince Dakkar, appears as Captain Nemo of the Nautilus, eager to sink British ships, and in L'île mystérieuse (1873) he is the mysterious helper of American soldiers who escape the Civil War and end up on an island which they turn into a wonderful place to be, clearly inspired by Robinson Crusoe.

57 [S]a orang pienter di dalam beberapa ilmoe; mendjadi sebab itoe segala tjeritaan pemboewatanja toean Jules Verne ada moeat pertoendjoekan dan pengadjaran jang baik, aken goena segala bangsa; terlebih aken goena saorang, jang berhendak menjampeken ketaoeannja hal ilmoe dan lain lain kapandean adanja. 
writers and readers, like Claasz himself, were supposed to travel: assimilate European knowledge, incorporate science, and become skilled and clever and modern. Apart from connecting narrative fragments at will, they should be able to travel to distant countries, talk about individual emotions, build machines that would make those awesome trains superfluous, transform their lands on the basis of scientific knowledge, and face big bangs. Their adventures would lead to future failures and explosions, to anxiety - and then to novel experiences and new adventures.

\section{A Malay tale}

Summaries are hard to make of any tale, as reading turns a tale into debris, into fragments that can be assembled into various configurations and organized around various themes. Romah asêp is no exception to this rule. The perspective from which the events are narrated - the detonator of every narrative and summary - shifts position more than once, and that does not make it easier to gain the distance necessary to identify the tale's knots and construct an interpretation: events are presented by an omniscient narrator, interrupted by notes from the journal of Maucler, a French visitor to India, who speaks of himself as kitaorang ('we') and thus invites his Malay readers to join him on his journey through this as yet unknown country and this omniscient narrator's tale. Again and again, Maucler's voice is interrupted by the voice of the other narrator, easily taken for Claasz's, in particular in the fragments about the adventures of the Indian protagonist Nana Sahib and his follower Kalagani, and in the retrospect upon the 1857 Mutiny against British power, pictured as a struggle between uninformed British soldiers and wilful Hindus. Facts and events take a fictional if not futuristic turn in Romah asêp: the Mutiny, a historical event, is followed by an imaginary conflict which, driven by a machine that is equally imaginary, is fought out between two persons who existed primarily in this narrative alone, with no conclusive victory for either. And yet, both seem to have moved around in the real world.

In May 1867, the narrative goes, the journey starts from Calcutta. The travellers are heading westwards on a 'trip through the continent of India' (besiar koeliling anteiro benoea India) - and of course they have maps at their disposal so that they are not dependent on ignorant and unreliable natives and do not have to consult any of the people living on that very imaginary map: the British already know the country, but not really. After passing through some famous cities, the iron monster turns north at the instigation of Colonel Munro, the unofficial leader of the group - and Maucler (and the others) comes to understand why their imaginary vehicle enters increasingly inhospitable terrain: Munro is in search of Nana Sahib, the man who 
allegedly killed his wife at Kawnpor during the 1857 Mutiny. There is plenty to talk about in the elephant's comfortable belly - and after viewing some castles, temples, and masses of people, the travellers turn their attention to nature and enjoy hunting tigers and other wild animals. In a number of chronologically parallel chapters, the adventures of Nana Sahib alternate with descriptions of the travellers' progress. Once he realizes the British are still searching for him, the Indian prince sends some trusted servants to spy on his enemies and starts plotting another revolt. Nana Sahib's ultimate aim is to become the ruler of India and kill all the British - 'the railroad between Bombay and Allahabad will be soaked in your people's blood!!', he shouts in one of his many moments of anger. His first target is Colonel Munro, whom he holds responsible for the death of his own wife in the same revolt in which Munro's wife had allegedly been killed.

The two main protagonists, Munro and Nana Sahib, are driven by revenge and rage. Maucler is just a curious man who watches the wonders that are India, describing some of them in his journal and trying to be as comfortable as possible. The other Europeans are primarily eager to kill tigers, and are occasionally stopped from doing so by nature as well as by a Dutchman, Van Guijtt, who is catching wild animals he wants to sell to European zoos. With its descriptions of temples, cities, and natural beauty, the first part of Romah asêp reads like a set of fragments from a modern travel account, but if anything, these descriptions are introduced by a confused traveller who has difficulty stepping out of the Malay lands: Hindu pilgrims in Benares are called hadji, Hindu temples are called geredja, the Ganges is called anak Allah, the proposed war of the Hindu prince against the British is called a perang sabil, royal palaces are kraton. The second part reads like another journey into the heart of darkness: the bloody hunting adventures are interrupted by virulent battles between Indian rebels and British soldiers. Eventually Munro and Nana Sahib do meet face to face, but their desire for revenge then takes strange turns. Munro is captured by the Indian nobleman, only to discover that his wife is still alive, wandering around like a ghost - and before his enemy can kill him, Munro manages to escape thanks to the help of his spectral wife and one of his Indian servants. In the ensuing pursuit, Nana Sahib, in his turn, is captured; he is tied to the iron elephant's trunk - and before the British can execute him, the iron monster explodes and the Indian prince vanishes from the earth, leaving the British travellers amid debris. Munro returns to Calcutta with his wife and his friends, and then they all go their own ways, the hunting companions enjoying the memory of their killing spree and Munro seeing to it that his wife loses her spectrality. Maucler leaves the country, as becomes a modern tourist. The narrator and we, kitaorang, leave the conflicts around the anti-European movement in India unresolved and even undisputed. And the question of the blessings of the future, spread by the explosion of the mechani- 
cal elephant, symbol of the superior European expertise and imagination soon to be acquired, remains unanswered in Maucler's journal, too.

An inconclusive tale about an imaginary monster that replaces a familiar vehicle and then is unable to defend itself against local fighters: Romah asêp should, above all, be read as an example of a certain form of science fiction. Claasz's creation can also be read as a tale of an unfinished journey, and as such it is tempting to read it as an allegory of human life, or perhaps of colonialism: the technical marvel of an iron machine, the future replacement of the despicable train, should have protected and guarded the British masters against the world of the local populace, but instead it explodes, leaving it to readers and heroes alike to draw their conclusions about the unfinished future from the narrative debris. The land seems in turmoil. The insurgent, Nana Sahib, has vanished but may return. The group of Europeans disintegrates, not understanding what is going on in India, unaware of their own ignorance. The future is dark and open. Perhaps another monster will be built. Perhaps Nana Sahib will emerge once more. Perhaps the European travellers will assemble in another futuristic machine, for another journey - so that they can be attacked once more.

\section{Pictures and printed words}

Romah asêp is embellished with numerous pictures, sinister and mysterious compositions, which must have made a deep impression on readers. ${ }^{58}$ They are organized in such a way that, beginning with the frontispiece, they seem to function like a cartoon strip, running parallel with the narrative itself; people who could not read the tale could look at the pictures and develop an understanding of the trail of its fragments. The text explains the pictures, the pictures follow the text in an uneasy interaction. ${ }^{59}$ And everyone can acquire some knowledge of what India and future trains are like, and then apply this 'knowledge and expertise' to life in the Malay lands.

\footnotetext{
58 'Toean Jules Verne' is explicitly named on the front page of Romah asêp; the illustrator is not. When the pictures in Van Dorp's publications are compared with their parallels in the French and Dutch publications, it is obvious that they are inspired by the pictures made by Léon Benett for European versions. In the 1880s some of Ijap Goan Ho's publications in Semarang had already been illustrated with anonymous sketches and drawings (Salmon 1981:564-5); clearly inspired by Chinese models, they must have equally served to make the words more understandable, the events better imaginable. Thus, the books are memorable illustrations of the 'spectacular realism' that was spreading over Java and beyond; in the same period, pictures were added to some of the China-based Malay tales published on the Peninsula (Proudfoot 1993:22).

59 The skeleton-like nature of Claasz's transposition of Verne's text is strengthened by the pictures that make long narrative descriptions unnecessary.
} 
Romah asêp is written in Low Malay, and thus Claasz's hikaijat primarily connects itself with the series of tales that had been produced by peranakan writers in Semarang and elsewhere in the 1880s. It presents its readers with forms of storytelling, characters, machines, and events which they also knew from the reports, tales, and advertisements of newspapers such as Selompret Melajoe, each of them episodic, porous, and brittle. Romah asêp, in short, echoed and incorporated elements not only of European tales but also of local newspapers. It also competed with the work of Yap Goan Ho and Tjhie Ang Lien (alias Correspondent Hindia XX) and competed for attention with the books of Von Dewall, written in stylized Malay about events completed long ago. The tale about the future train expanded the configuration of Malay writing, that formation of memorable texts in Malay which, by emulating Chinese, European, and Javanese tales, allowed the gradual emergence of the concept of 'literature', its contours taking shape in the layers and lines created by readers on the debris of ever new explosions in the closing decades of the nineteenth century.

The explosions of Romah asêp had a climax, so to speak, in the explosion of the iron monster: its debris sank into abeyance, its fragments vanished from the Malay lands, leaving it open to us to find out which (and how many) elements may have found their way back to newly printed materials, with a vengeance. It is even harder to imagine the effect on readers of the pictures accompanying the printed words.

\section{Surveys and textbooks}

'Modern' is a word we use to organize our memories of the more recent past in which some things happened that can be described in terms of a counterforce. Neither the nineteenth-century passenger in the train to Solo nor the tourist Maucler in the iron monster outside of Calcutta was aware of being modern, or of the emergence of modernity, for that matter. We think we are. The same could be said of 'literature': when they first appeared, early printed tales such as Romah asêp showed little awareness of being 'literary'; only in retrospect do they offer their readers the possibility of calling them 'literary work', central in the hierarchy of the configuration of Malay discourse. In order to test their strength and to position them, we have to make these early tales explode again and again by reading them - and by doing so we are running the risk of condemning the resultant debris to silence once again. Romah asêp is a case in point: Claasz's book has never been mentioned in any textbook of Malay writing, let alone incorporated in the canon of Malay literature. His work seems to have vanished from the earth, apart from copies kept in a library or two.

Trains suggest 'modernity'. Textbooks evoke 'literature'. People who travel in a train are offered ever changing views upon the world, serial and shocking 
- and people who read a textbook are offered ever shifting visions of printed materials, including 'literature', which, in one way or another, reflect the world where elements of the 'language' in which they are written are wandering around invisibly, together with modernity, in search of novel assemblages. Trains may explode, books may explode - and the dismissal of trains is as intriguing as the dismissal of textbooks: other machines will emerge, other textbooks will appear. There is also a fear of failure involved: sooner or later it may be impossible to assemble the fragments and debris of the experiences of travelling, looking, and reading, and then no new trains and textbooks may materialize - and notions of 'modernity' and 'literature' may vanish.

The available textbooks on 'Malay literature' tend to discuss the second half of the nineteenth century in the Malay lands with great evasion if at all: it has been made a period of oblivion and silence in which manuscripts were produced and reprinted, read and sold. Referring to it as a 'period of transition', critics and scholars - the people who create networks of communal knowledge by way of surveys, evoking a literary canon in the process - confine themselves to an obligatory sketch of how in the Malay lands the manuscriptal tradition was gradually losing prominence after the introduction of printed materials and how lithographed texts in Jawi were competing for prominence with printed books in Wolanda script as well as with periodicals.$^{60}$ In the sketchy descriptions of this 'period of transition', storybooks are embedded in the 'tradition'. Just one or two titles, authors, or publishers are mentioned - and the vitality of the nineteenth-century publications and the volatility of the explosions which led to fragmentation and assemblages and novel tales and new explosions go unnoticed and unappreciated. As if no novel Malay writings had been published and appreciated between, say, Abdullah Abdulkadir, on the one hand, and Tirto Adisoerjo, Mas Marco Kartodikromo, and Syed Sheikh al-Hadi, on the other. Or between Ahmad Talu and Raja Ali Haji, for that matter. The Wolanda work of, for instance, Lie Kim Hok, Yap Goan Ho, Chan Kim Boon, Von Dewall, Wiggers, and Claasz tends to be ignored, and the same holds for the Jawi writings of Husain bin Enci Musa, Haji Mohd. Said, and Mohd. Eunos Abdullah. What happened to their explosive creations, to the web of lines and layers that emerged from the debris produced in reading them? As if the echoes of their readings, the explosions of their writings, have forever faded away or were never even heard.

For one, those were the years when the basis was laid for 'literature', a modern concept, not only connected with trains, newspapers, streetlights, and money orders, but also with printing presses that invoked fiction as well

60 'Prominence' is a term that is closely related to notions of hindsight and bias - at the time of their appearance, it would have been very hard indeed to substantiate the claim that manuscripts were losing their authority to books. And yet they were. 
as experiences of belonging to communities beyond the borders of village or city, and even beyond the confines of an ethnic group and its predominant language. 'Malay literature' with its notions of novelty, imagination, factuality, and artfulness was to play an important formative role in the experiences of belonging to a nation. Nationalism was waiting in the future - and the Malay lands were expanding through people's acts of reading.

The books initially published presented tales that referred to faraway places, not only in terms of their so-called 'authors' (a term closely linked with 'literature') but also in terms of their topics: China, Europe, India, and the Middle East. Not until the turn of the twentieth century did books begin to appear which, conceived by 'locals' or 'natives', referred to the Malay lands themselves. Those were the very years when the idea of books 'for all nations' (aken goena segala bangsa) was becoming increasingly questionable if not inconceivable, the result of the imposition of the Law. Natives were assumed to write primarily for natives, ethnic Chinese for ethnic Chinese, Europeans for Europeans. It was to show in the forms of Malay, in the protagonists, in the adventures. Even in an intellectually vibrant place like Semarang, nationalism was to be unable to hold the people in the Malay lands together in a shared structure of feeling - and unfortunately the budding literary canon was not either.

China-inspired texts by Yap Goan Ho and Lim Ho Hin. Europe-inspired texts by authors such as Claasz, Von Dewall, and Wiggers. Java-inspired tales by Kommer, Tio Ie Soei, and Tirto Adisoerjo. Peninsula-inspired tales by Ahmad Kotot and Ahmad Talu. Creations of the ethnic Chinese peranakan were prominent in what could be called 'the beginnings of modern Malay literature', but before long they lost control over the layers and lines they were opening up - and in their dialogues with the compositions of authors such as Claasz and Von Dewall as well as with reviews in contemporaneous periodicals such as Courant Deminggoe dari pada Bintang Barat, Malay literature blew up into bits and pieces that were never brought together again except in terms of conflicts and silences.

Romah asêp did not visibly or perceptibly survive initial readings. How to account for this readerly dismissal? Its oblivion is no doubt due to the fact that Claasz's creation was composed in 'Low Malay', loose forms of discourse whose authority was questioned first by more consistent variants of written 'Malay', and then pushed aside by an increasingly centripetal form of Malay that, modelled on Von Dewall's publications, was to gain authority over writing as 'standard' and 'canon'. ${ }^{61}$ Its oblivion was also due to the fact that the

61 Probably because of their names alone, authors such as Claasz, Wiggers, and Francis were never connected with Chinese peranakan authors who, operating in growing defiance of 'Van Ophuijsen Malay', were to realize that they developed a literary tradition of their own. 
tale, told in something of a science fiction manner, introduced the successor of the train before the train itself, icon of modernity, had become a familiar phenomenon in the lands of Malay readers; its main hero was too imaginative, so to speak, its adventures too futuristic, and its ending too inconclusive. ${ }^{62}$ Romah asêp's debris seems to have vanished into thin air, too, because it was soon considered a mere translation, ${ }^{63}$ and once notions of author and origin emerged in competition with notions of performance, assimilation, and incorporation, interlingual transpositions - acts of resistance and creativity as much as of imitation and repetition - lost their visibility in every conceivable textbook of Malay literature. The fact that these 'translations' were Malay texts and that their debris coagulated with fragments of 'original' texts made into new Malay texts was never seriously taken into account. 'Translations' may find their way into discussions about world literature (Damrosch 2003:6), but they are not supposed to lead to explosions relevant to describing and comprehending a nation's literary life.

But then, what is a textbook of Malay literature if not a descriptive evocation, no matter how porous, of the dynamics of Malay writing, suggesting lines between conflicting movements, dialogues, themes, and forms against the background of individual authors, particular tales, and singular situations? And what is a survey if it does not explore explosions, debris, and fragments rather than comprehensions, origins, and entities? And have 'translations' not always played a prominent role in Malay writing - that is, since time immemorial?

Against the background of Jules Verne's lengthy La maison à vapeur, ${ }^{64}$ Romah asêp is a rather thinly fleshed skeleton. Details of the French text are omitted from the Malay text, and details being the elements that steer every

62 The fact that science fiction was to remain a largely unexplored genre in Malay writing until the twenty-first century is worth another question mark.

63 In conventional terms, Romah asêp is a Malay adaptation of a Dutch translation of the French original, which was first published in instalments in Le Magasin d'Éducation et de Récréation in 1879-1880, then in two volumes in 1880, under the title La maison à vapeur. The (anonymous) Dutch translation was first published in two volumes by Elsevier in Amsterdam in 1882, under the titles De ijzeren reus and De waanzinnige der Nerbudda.

64 Apparently Verne and his publisher, Hetzel, were never aware of the fact that some of their tales were translated in Malay and published in Semarang and Batavia. They may have exploded with commercial anger had they known about them: they missed out on possible royalties - were writing and printing and publishing not about money in Europe, too? - and, secondly, they would have realized sooner or later that the Malay translations were as 'bad' and 'incomplete' as the English and American ones. Perhaps there was yet another reason Van Dorp and Claasz did not deem it necessary to ask for permission: these were Malay tales. Inspired by the work of a man so far away, these were first and foremost Malay reassessments, acts of resistance to tales that had come wandering to Java, just like newspaper reports, just like the tales of Arjuna, Rama, and the Prophets, just like the Chinese tales around them. 
attempt at interpretation, Claasz's Malay text leads to explosions that do not converge with the fragments that could be generated from Verne's French tale. A corresponding leanness can be found in the transposition of Benett's pictures into their Malay versions: some of them are completely omitted; those that are imitated may be equally dark and sinister yet they are sketchy. Tracing such interactions, however, is probably not the way to go in making sense of this tale about an iron monster on its tour through India - and the fact that Romah asêp is based on a Dutch rendition of a French original may make the question of the book's origins and beginnings even more confusing. Given its succinctness and lightness, it is more rewarding to read the tale as a reformulation of the printed Malay tales of adventure that, available in Semarang around the same time, take place in China: Romah asêp is not so much a distant variation on Verne's French novel as a discursive play on Malay tales about China. They all point at new contexts for acting out life in the Malay lands, and such novelties deserve a place in every survey of Malay writing. Romah asêp's perky phrases and bumpy sentences about adventures in a faraway country generated novel energies in Malay writing every time they were exploded - and they still do.

Its linguistic vitality aside, Claasz's tale should be foregrounded for its own Malay sake for yet another reason. It showed its readers a way beyond their own city, beyond the Malay lands, beyond Never-Never Land, and beyond China - and that journey would ultimately bring them back to their own world again. Hikajat Robinson Crusoe, Barang rahsia dari astana Konstantinopel, Graaf de Monte Cristo, Romah asêp: they offered exciting readings, strong enough to reward every endeavour of tracing their debris within the ever transforming assemblage of Malay writing. These were Malay tales. They explored the force of Malay in novel ways. They introduced and examined notions and devices of factuality, subjectivity, and fiction. In their capacity to stimulate conversations and dialogues, they opened the way to printed Malay tales about daily life, about robberies, assassinations, machines, and racial tensions in the Indies, and later in the Straits Settlements. In short, they played a crucial role in the dynamics of the Malay discursive formation in which, driven by the noise of their explosions, the notion of 'literature' was emerging as a form of writing that operated just like trains, as a form of reading that operated just like a train ride, straight ahead into the literary future, offering ever shifting Malay views on the world. ${ }^{65}$

65 The vignette-like sketch of a train journey that opens this essay plays on a passage in Pramoedya Ananta Toer (1980:105-6) where notions of temporality, anxiety, boredom, nationalism, views, movement, silence, and conversations are brought together in a description of the train ride which the tale's main hero, Minke, is forced to make through Java in 1898; he is to wait upon his parents, representatives of the memories which he, the modern traveller, is trying to escape in his volatile explorations of the open-ended future of the twentieth century. 


\section{References}

Abrams, M.H.

1988 A glossary of literary terms. Fifth edition. New York: Holt, Rinehart and Winston. [First edition 1957.]

Adam, Ahmad

$1995 \quad$ The vernacular press and the emergence of modern Indonesian consciousness (1855-1913). Ithaca NY: Cornell Southeast Asia Program.

Claasz, W.N.J.G.

1895 Romah-asêp (Stoomhuis); Satoe tjarita dari toean Jules Verne: Tertjaritaken di dalem bahasa Melaijoe renda. Semarang: Van Dorp. Two vols.

Damrosch, David

2003 What is world literature? Princeton NJ: Princeton University Press.

Davis, Lennard J.

$1983 \quad$ Factual fictions; The origins of the English novel. New York: Columbia University Press.

Derrida, Jacques

1985 'From "Des tours de Babel"', in: Joseph F. Graham (ed.), Difference in translation, pp. 165-208. Ithaca NY: Cornell University Press.

Jedamski, Doris

2002 'Popular literature and postcolonial subjectivities; Robinson Crusoe, the Count of Monte Cristo and Sherlock Holmes in colonial Indonesia', in: Keith Foulcher and Tony Day (eds), Clearing a space; Postcolonial readings of modern Indonesian literature, pp. 19-47. Leiden: KITLV Press. [Verhandelingen 202.]

Kroeskamp, $\mathrm{H}$.

$1974 \quad$ Early schoolmasters in a developing country. Assen: Van Gorcum.

Milner, A.C.

1994 The invention of politics in colonial Malaya. Cambridge: Cambridge University Press.

Oeij Peng Long

1891 Boekoe sair roepa-roepa seperti Sair orang bersobat, Sair Nona Boedjang dan Sair segala boea-boeahan. [Batavia]: n.n.

Oey Tjoen Bin

$1890 \quad$ Boekoe Sin Tjong. Batavia: Yap Goan Ho.

Pramoedya Ananta Toer

1980 Bumi manusia. Jakarta: Hasta Mitra.

Proudfoot, Ian

1992 Early Malay printed books. Canberra: Faculty of Asian Studies.

Putten, Jan van der

1995 'Taalvorsers en hun informanten in Indië in de 19e eeuw; Von de Wall als politiek agent in Riau?', Bijdragen tot de Taal-, Land- en Volkenkunde 151:44-75.

Putten, Jan van der and Al Azhar (eds)

1995 Di dalam berkekalan persahabatan - In everlasting friendship; Letters from Raja Ali Haji. Leiden: Department of Languages and Cultures of Southeast Asia and Oceania, University of Leiden. [Semaian 13.] 
Queljoe, E. de

$1884 \quad$ Timpalan sair mengimpi dan Sair boeroeng. Batavia: Kolff.

Quinn, George

1992 The novel in Javanese; Aspects of its social and literary character. Leiden:

KITLV Press. [Verhandelingen 148.]

Regensburg, Alex

$1893 \quad$ Hikajat roh manoesia. Batavia: Regina Orientis.

Rodgers, Susan

2002 'Compromise and contestation in colonial Sumatra; An 1873 Mandailing schoolbook on the "wonders of the West"', Bijdragen tot de Taal-, Land- en Volkenkunde 158:479-512.

Salmon, Claudine

1974 'Aux origines de la littérature sino-malaise; Un sjair publicitaire de 1886', Archipel 8:155-86.

1979 'Lawah-lawah merah, ou "L'Araignée Rouge"; Un "roman sino-malais" qui s'avère être la traduction d'un roman français', Archipel 17:63-9.

1981 Literature in Malay by the Chinese of Indonesia. Paris: Éditions de la Maison des Sciences de l'Homme.

1988 "The Batavian Eastern Railway Co. and the making of a new "daerah" as reflected in a commemorative syair written by Tan Teng Kie (1890)', Indonesia 45:49-62.

Sjair Tan Sha-Go Nio

1896 'Sjair Tan Sha-Go Nio', in: Almanak Melajoe. Batavia: Albrecht en Rusche.

Sykorsky, W.V.

1980 'Some additional remarks on the antecedents of modern Indonesian literature', Bijdragen tot de Taal-, Land- en Volkenkunde 136:498-516.

Tan Keng Kie

[1891] Sja'ir djalanan krèta api ja'itoe Bataviasche oosterspoorweg dengan personeelnja bij gelegenheid van de opening der lijn Tjikarang-Kedoeng-Gedé bezongen. Batawi: Regensburg.

1898 Sair kembang. Batavia: Tjoe Toei Yang.

Tan Tjhan Hie

1897 Sair ikan. Batavia: Albrecht.

Termorshuizen, Gerard

1988 P.A. Daum; Journalist en romancier van tempo doeloe. Amsterdam: Nijgh en Van Ditmar.

2003 Journalisten en heethoofden; Een geschiedenis van de Indisch-Nederlandse dagbladpers 1744-1905. Amsterdam: Nijgh en Van Ditmar.

The T.L.

1888 Boekoe pantoon. Soerabaja: Grimberg.

Uilkens, J.A.

1885

Indische typen. Amsterdam: Brouwer. 
Wilkinson, R.

1959 A Malay-English dictionary (romanized version). London: Macmillan.

Williams, Raymond

1977

Marxism and literature. Oxford: Oxford University Press. [Marxist Introductions.] 